\title{
National Policies and Strategies for the Support of the Gifted and Talented in Austria
}

\author{
Claudia Resch ${ }^{1}$
}

$\approx$ The approach to the support of gifted and talented children and youth has changed considerably in the past twenty years. While, until the 200os, provision programmes predominantly focused on extracurricular activities for pupils, gifted education now follows a systemic and inclusive approach, including all (educational) institutions - kindergarten, school, college and university - as well as the family, the economy, the working world and the community. Furthermore, there have been considerable efforts to provide for gifted children within the regular classroom by way of differentiation and individualised learning.

This new approach to talent support was first outlined in 2011 in the "White Paper Promoting Talent and Excellence", which the Austrian Research and Support Centre for the Gifted and Talented published in cooperation with the interministerial Giftedness Research and Gifted Education Task Force.

The present article outlines the reasons that led to this new strategy, explains its main features and attempts an analysis of its strengths and weaknesses.

Keywords: Austria, gifted education, holistic, systemic, talent support

1 Austrian Research and Support Centre for the Gifted and Talented (Österreichisches Zentrum für Begabtenförderung und Begabungsforschung - ÖZBF), Salzburg, Austria; claudia.resch@oezbf.at 


\section{Nacionalne politike in strategije za podporo nadarjenim in talentiranim $\mathrm{v}$ Avstriji}

Claudia Resch

$\propto \mathrm{V}$ zadnjih dvajsetih letih se je podpora nadarjenim in talentiranim otrokom ter mladim zelo spremenila. Medtem ko so bili do leta 2000 programi za učence večinoma usmerjeni v zunajkurikularne dejavnosti, je zdaj pristop pri izobraževanju nadarjenih sistematičen in inkluzivno usmerjen. Vanj so vključene vse (izobraževalne) ustanove - vrtci, šole, srednje šole in univerze - pa tudi družina, gospodarstvo, zaposlovanje in skupnost. Veliko dela je bilo vloženega $v$ to, da se nadarjenim učencem zagotovi podpora $\mathrm{v}$ rednih razredih prek diferenciranega in individualiziranega učenja. Ta novi pristop podpore talentiranim je bil prvič poudarjen leta $2011 \mathrm{v} »$ White Paper Promoting Talent and Excellence» [Bela knjiga o spodbujanju talentov in odličnosti], ki jo je avstrijski Center za raziskovanje in spodbujanje nadarjenih in talentiranih izdal v sodelovanju z medresorsko skupino »Giftedness Research and Gifted Education Task Force«. V prispevku so navedeni razlogi, ki so vodili do oblikovanja nove strategije, razložene so glavne značilnosti, predstavljena pa je tudi analiza prednosti in slabosti sistema.

Ključne besede: Avstrija, izobraževanje nadarjenih, celostna in sistematična podpora talentiranim 


\section{The development of gifted and talented provision in Austria - from separative measures to a holistic and systemic approach}

Since the mid 1990s, the issue of gifted and talented provision ${ }^{2}$ has become increasingly important in education policy in Austria. Especially over the past five years, politicians and other important stakeholders (economists, researchers, etc.) have focused on this topic, and the interest of the media has been growing. However, this has not always been the case. In the 1980s, gifted and talented education was still highly controversial in Austria. Three reasons can be assumed for this opposition:

1. Due to the Nazi regime, which propagated the training of an elite (in the worst sense possible), the term "elite" had a severely negative connotation. After World War II, gifted education was believed to support this elitist thinking, and was therefore strongly opposed (Ziegler \& Stoeger, 2007).

2. A commonly held belief and prevailing view of the public was (and sometimes still is) that gifted children and adults do not need any further support measures, simply due to the fact that they are already gifted and able to perform well by themselves. The underlying assumption was that only pupils with learning difficulties need support.

3. Austria has a differentiated school system. While all children attend primary school from age 6 to 10, pupils have to choose between secondary modern school ("Hauptschule" or "Neue Mittelschule") or grammar school ("Gymnasium", aimed at higher-achieving pupils) at the age of 10. ${ }^{3}$ Until the 1990s, it was commonly believed - by representatives of both school types - that this early tracking of pupils would lead to the creation of two homogeneous learner groups, thus making a differentiated approach focused on special gifts and talents in schools redundant. However, since the 1980s, more and more pupils have chosen to attend grammar schools, and in some areas over $50 \%$ of all pupils nowadays go

2 For a definition of giftedness, see section The concept and terminology of giftedness.

3 "Hauptschule" or "Neue Mittelschule" ("Hauptschule" is currently being reformed and will be called "Neue Mittelschule" from 2015 onwards, but will aim at the same learner group) lasts four years, and children who attend this school have several options afterwards. They can continue schooling for one year and then start an apprenticeship, they can attend a so-called middle vocational school, taking three (sometimes four) years and then start work, or they can attend a school that finishes with "Matura" (A-levels). This school might either be a "Gymnasium" (four years until "Matura") or a higher vocational school that takes five years until "Matura". If pupils choose to attend a "Gymnasium" after primary school, they can either finish with their "Matura" after eight years of schooling, or change to one of the aforementioned higher vocational schools after grade 8 , or even start an apprenticeship after their $9^{\text {th }}$ year of compulsory schooling. 
to these schools (Schwabe \& Gumpoldsberger, 2008).

With more and more pupils attending grammar schools, and a correspondingly more diverse school population, it became increasingly clear that special provisions for gifted children were a necessity; not only for grammar schools, but also for primary and secondary modern schools.

The first measures (to be supported by legislative action, see section Legal framework) taken regarding gifted education were:

- In the mid 1980s, the first extracurricular talent courses for highly gifted pupils were offered in Salzburg, and soon afterwards in other Austrian regions as well.

- In 1988, one of the first large European conferences on the promotion of the highly gifted took place in Salzburg, which was attended by over 600 people from 23 countries. Although it was accompanied by massive protests in front of the venue, it nevertheless stimulated a broad discussion about the needs of gifted children and the necessity of gifted education (Rosner, 2004).

- In 1996, the former Federal Ministry of Education, Culture and Science established a unit for the provision of the gifted and talented. Consequently, the president of each provincial school board was asked to nominate consultants for gifted education in their province. These consultants now act as provincial coordinators (for a description of the coordinators' tasks, see section Coordination of gifted and talented support activities in Austria).

- In 1997, the province Upper Austria organised the first summer school for highly gifted pupils, and summer schools are now being organised in all of the nine provinces.

- In 1998, a special grammar school for highly gifted and talented children was established in Vienna, the Sir Karl Popper School. The establishment of the school was - like the aforementioned conference in 1998 - also accompanied by strong protests, showing that support for gifted education was still lacking in Austria.

- In 1999, the Austrian Research and Support Centre for the Gifted and Talented, or ÖZBF (Österreichisches Zentrum für Begabtenförderung und Begabungsforschung), was founded (Weilguny, Resch, Samhaber, \& Hartel, 2013).

The original intention behind the establishment of the ÖZBF was to respond to the demands of parents and teachers for diagnostics and counselling, 
as well as to initiate extracurricular provision measures for gifted children. Soon, the ÖZBF realised that these steps, as valuable and necessary as they were, would not lead to a fundamental change for gifted children, let alone the school system's approach to gifted education. The reasons for this were as follows:

- It was increasingly recognised that it was not enough to deal with the provision for gifted children only in schools, but that other educational institutions (or "fields"), such as the kindergarten, the university or the family, needed to focus on gifts and talents as well.

- The more counselling centres and special schools or classes for gifted children were being established, the less regular schools, or teachers in general, felt obligated to identify or provide for gifted children within the classroom.

- It became apparent that it was quite unsatisfactory for most children to receive challenging tuition in extracurricular activities (which usually took place once a week for two hours), while being bored and under challenged for the remainder of the school week (Weilguny \& Rosner, 2012).

- There was general discontent over the fact that separative provision measures were predominantly attended by pupils from a higher socioeconomic background. Certain groups, such as children with migrant backgrounds, a lower socioeconomic status or learning difficulties, were usually not considered for these extracurricular activities. This, however, meant that a considerable proportion of the school population was not receiving the provision it needed.

As a consequence, the ÖZBF shifted its focus from separative measures for a few to a holistic and systemic approach including all (educational) institutions - kindergarten, school and university - as well as the family, the economy, the working world and the community. Since this shift, the ÖZBF has been working in the following areas in order to guarantee the continuous development of young peoples' gifts and talents:

- It develops educational strategies and concepts at national and regional levels.

- It supports school quality development.

- It trains teachers and educators of all educational institutions.

- It develops curricula for initial and inservice training in gifted education.

- It carries out research in the field of applied gifted education and processes the findings for practical use. 
- It establishes networks and cooperation to support all of those engaged in gifted education and the promotion of excellence.

- It organises conferences to raise awareness and increase professionalisation.

In general, a special concern of the ÖZBF is to establish a positive approach towards gifted education and to promote excellence by providing information, thus creating an awareness for a talent-friendly and challenging environment.

\section{The White Paper Promoting Talent and Excellence}

In 2011, the ÖZBF published the "White Paper Promoting Talent and Excellence" ${ }^{4}$ in cooperation with the Giftedness Research and Gifted Education Task Force. The Task Force, which was founded in 2008, is an interministerial steering committee with experts from the Ministry of Education and Women's Affairs, the Ministry of Science, Research and Economy, and the ÖZBF. It meets several times a year to develop and discuss strategies for gifted education and giftedness research in Austria, and to find ways for their implementation.

The White Paper calls for the promotion of talents and excellence in every (educational) institution (so-called "fields of action"), ranging from kindergartens, schools and universities to adult education facilities, communities and companies. It describes how the promotion of talents can be implemented in each of these fields of action. Furthermore, the White Paper discusses the importance of research, the creation of support and research networks, and the relevant training for teachers and counsellors.

In the continuation, some chapters of the White Paper will be presented in more detail, in order to outline the current situation of talent support in Austria.

\section{The concept and terminology of giftedness}

The White Paper is based on a multidimensional and dynamic conception of giftedness and talent, encompassing a person's overall potential, which unfolds through lifelong learning and development. Hence, giftedness and talents are not statistical figures but processes, resulting from the interaction between people's individual predispositions, their ability to shape their own development, and the influences of nurture (Weilguny, Resch, Samhaber, \& Hartel, 2013).

4 German edition published in 2011, English edition published in 2013. 
As the development of abilities results from the interaction of various factors, potential does not necessarily lead to extraordinary achievement. Even very high intelligence, in terms of outstanding reasoning and problem-solving abilities, is just one of many factors, and is therefore an insufficient predictor of high-level achievement. Besides cognitive abilities, the will to achieve, interest in relevant domains, work discipline, self-confidence, and self-monitoring skills are necessary prerequisites for a person to excel. Thus, the promotion of giftedness, talent and excellence focuses on a variety of factors (International Panel of Experts for Gifted Education, 2009).

The goal of promoting talent is to support the development of potentials in all children and youth in the best possible way. All children and youth, regardless of the level of their abilities, can benefit from gifted education, the underlying assumption being that they all possess potentials that are yet to be developed (Oswald \& Weilguny, 2005). Promoting the gifted and talented is one aspect of general talent promotion; it usually focuses on children and youth who have already been identified as outstandingly able and motivated, i.e., people who are said to be blessed with giftedness.

Promoting excellence is less focused on potentials to be developed, and more on the perfection and elaboration of outstanding achievement in a given domain that has already become apparent. The promotion of excellence is therefore based on the successful promotion of talent (Weilguny, Resch, Samhaber, \& Hartel, 2013).

\section{Coordination of gifted and talented support activities in Austria}

In Austria, talent support activities are coordinated on several levels. The Austrian Federal Ministry of Education and Women's Affairs and the Ministry of Science, Research and Economy are jointly in charge of the legal and financial foundations for gifted education. The federal Ministry of Education and Women's Affairs funds and supervises primary, secondary and, since 2000, also post-secondary education (teacher training colleges) ${ }^{5}$ while the federal Ministry of Science, Research, and Economy is responsible for promoting excellence at universities and initiating research on giftedness. Both ministries have established units for the provision of the gifted and talented, which cooperate with the institutions and individuals mentioned below.

The ÖZBF is the national institution for the further development of gifted education and the promotion of excellence in Austria. Financed by the

5 In Austria, primary and secondary school teachers are trained at teacher training colleges, while grammar school teachers are trained at universities. 
two aforementioned ministries, it supports individuals, institutions and initiatives promoting young people's gifts and talents. Being financed by the state, and therefore having a federal mandate to initiate gifted education, the ÖZBF is unique in Europe.

On the state level, every province has a coordinator for talent support. These coordinators, as has already been mentioned, were appointed in 1996. They organise summer academies and other regional activities for the gifted and talented, they provide inservice training for teachers, and to some degree also act as counsellors for parents and teachers of gifted and talented children. The coordinators come from various professional backgrounds: most have worked as teachers (either in primary, secondary or grammar schools) and some are school psychologists. They often do not work full-time as coordinators, but instead tend to remain in their teaching or counselling jobs part-time. Although there are no specific requirements with regard to training and qualification, most coordinators either have an ECHA certificate or a similar qualification.

At the local level, part-time county coordinators are currently being established. They will provide counselling for schools, teachers, parents and gifted and talented children. The goal is to establish a coordinator for the gifted and talented at each school, kindergarten and university. At present, however, there is only one province that has established school coordinators. They usually spend one to two hours per week on implementing measures and counselling parents, pupils and colleagues at their school (Weilguny, Resch, Samhaber, \& Hartel, 2013).

Although the Ministry of Education and Women's Affairs is generally responsible for funding and supervising primary and secondary education, the nine provincial school boards have the possibility of allocating more resources to gifted education if they wish to do so. This has led to considerable differences between the respective provinces. Whereas some provinces have only one coordinator and none at the local level, other provinces invest hundreds of thousands of Euro in gifted education and pursue a very systematic approach regarding identification and provision in schools.

At the kindergarten and university level, there are at present hardly any coordinating initiatives.

\section{Legal framework}

The provision and identification of the gifted and talented has also been introduced into the educational law, not only on the school level but also with regard to kindergarten. The most important document for kindergarten is a 
resolution between the Federal Republic and the Austrian provinces to establish a uniform educational framework for all Austrian elementary educational institutions. In autumn 2009, the "Supra-Regional Educational Framework for Elementary Educational Institutions in Austria" took effect, pointing out children's different interests, abilities and needs, as well as their various expressions and competences (Charlotte Bühler Institut, 2009). Furthermore, the concept of talent appears in statements on differentiation, early learning and inclusive education.

At the school level, gifted education was mentioned for the first time as early as in 1974. Since 1974, the School Education Act has offered gifted and talented pupils the opportunity to skip grades. Subject to the suitability and potential of the individual child, pupils can skip grades up to three times during their school career. One criterion, however, is that nine years of compulsory schooling must be completed.

Electives as well as school clubs and societies were mentioned explicitly as ways of promoting interested and gifted pupils in a 1988 revision of the School Organisation Act.

Section 45 of the School Education Act states that staying away from school "for important reasons" can be authorised by the class teacher or principal. In a decree issued by the Federal Ministry in 1998, this section was interpreted in favour of promoting the gifted and talented. Since then, attending university courses has been deemed "an important reason" for gifted and talented pupils to stay away from school. Thus, pupils can attend university courses during class time, and the attendance of these courses can be credited to the respective university course after graduation.

The decree "Better Fostering", which was issued to all schools in 2005, requires all pupils to be fostered individually, which represents a major prerequisite for the promotion of talent and excellence. Schools are called on to specify their principles of differentiation and individualisation in a general educational framework. This decree also mentions the promotion of particularly able pupils (Federal Ministry of Education, Science and Culture, 2005).

Since September 2006, statutory regulations concerning early school entry have been taking better account of the needs of gifted and talented children. The dispensation period for children who have not yet attained the age of compulsory schooling was extended, i.e., children whose development is significantly advanced may enter school if they complete their sixth year by March 1 (before 2006: December 31) of the following year.

The decree "Initiative 25+: Individualising Instruction" (2007) emphasises once more the importance of individualisation for managing heterogeneity 
and diversity, placing pupils' individual personality and learning prerequisites at the heart of instruction (Federal Ministry of Education, Arts and Culture, 2007).

The "General Decree on the Promotion of Giftedness and Talent" (2009) is explicitly devoted to talent development. The decree describes giftedness and talent as potentials for outstanding achievement, which can only develop in interaction with personality and environmental factors. It is the duty of schools to foster these potentials. As basic principles for the promotion of giftedness and talent, the decree mentions focusing on strengths and interests, accepting and supporting giftedness in an unbiased way, using a variety of fostering measures, and integrating the promotion of giftedness and talent into the overall school culture. In-class fostering includes the identification of characteristics that are relevant to giftedness and talent, the application of concrete educational measures, and the provision performance feedback in a way that enhances motivation. Wherever possible, parents should be involved in fostering activities (Weilguny, Resch, Samhaber, \& Hartel, 2013).

Table 1. Legislative measures in schools and their impact on the fostering of gifted pupils

\begin{tabular}{|c|c|c|}
\hline Year & Measure & Impact \\
\hline 1974 & $\begin{array}{l}\text { Skipping grades is made possible } \\
\text { for gifted pupils. }\end{array}$ & $\begin{array}{l}\text { Although there are, unfortunately, no statistics on } \\
\text { how many pupils have actually skipped grades since } \\
\text { 1974, it seems to be the case that skipping grades, } \\
\text { which was relatively unpopular and unknown in } \\
\text { the } 1970 \text { s and } 1980 \text { s, has increasingly been used } \\
\text { as a means to promote gifted pupils (especially in } \\
\text { primary school). }\end{array}$ \\
\hline 1988 & $\begin{array}{l}\text { Electives, school clubs and socie- } \\
\text { ties were mentioned explicitly } \\
\text { as ways of promoting interested } \\
\text { and gifted pupils. }\end{array}$ & $\begin{array}{l}\text { Electives have become extremely popular in } \\
\text { Austrian schools. However, they tend to promote } \\
\text { interests rather than gifts and talents. }\end{array}$ \\
\hline 1998 & $\begin{array}{l}\text { Pupils can officially "stay away } \\
\text { from school for important } \\
\text { reasons" to attend university } \\
\text { courses. }\end{array}$ & $\begin{array}{l}\text { Since the re-interpretation of this law, over } 500 \\
\text { pupils have used this possibility to attend university } \\
\text { courses through the programme "Pupils Attending } \\
\text { University". }\end{array}$ \\
\hline 2005 & $\begin{array}{l}\text { "Better Fostering" Decree: } \\
\text { schools have to specify their } \\
\text { principles of differentiation and } \\
\text { individualisation in a general } \\
\text { educational framework, which } \\
\text { should also specifically include } \\
\text { gifted pupils. }\end{array}$ & $\begin{array}{l}\text { Although this decree was a first important step } \\
\text { towards the fostering of gifted pupils (by simply } \\
\text { mentioning them as a group), budgetary cuts } \\
\text { limited schools to using special courses for lower- } \\
\text { achieving pupils. }\end{array}$ \\
\hline 2006 & $\begin{array}{l}\text { Early School Entry: children can } \\
\text { enter school at the age of five (if } \\
\text { they complete their sixth year by } \\
\text { March } 1 \text { of the following year). }\end{array}$ & $\begin{array}{l}\text { This is very similar to skipping grades: early school } \\
\text { entry has been used increasingly as a means to } \\
\text { promote gifted children in the past ten years. }\end{array}$ \\
\hline
\end{tabular}




\begin{tabular}{lll}
\hline 2007 & $\begin{array}{l}\text { The Decree "Initiative 25+: Indi- } \\
\text { vidualising Instruction": empha- } \\
\text { sises once more the importance } \\
\text { of individualisation for managing } \\
\text { heterogeneity and diversity. }\end{array}$ & $\begin{array}{l}\text { Class size has been limited to } 25 \text { pupils (previously } \\
\text { up to 30, sometimes } 35 \text { pupils), which should leave } \\
\text { more time for individualisation. }\end{array}$ \\
\hline 2009 & $\begin{array}{l}\text { "General Decree on the } \\
\begin{array}{l}\text { Promotion of Giftedness and } \\
\text { Talent": schools and teachers } \\
\text { are requested to foster gifted } \\
\text { pupils through individualisation, } \\
\text { differentiation, acceleration and } \\
\text { enrichment. }\end{array}\end{array} \quad \begin{array}{l}\text { Although most requests in the decree are indeed } \\
\text { requests or simply recommendations, which are not } \\
\text { legally binding, the decree offers those teachers } \\
\text { who want to foster gifted pupils the justification to }\end{array}$ \\
\hline
\end{tabular}

\section{Qualification of educators}

If the promotion of giftedness and excellence is to be an integral part of all of the different fields of action, it is of utmost importance that all educators regard themselves as potential promoters of gifts and talents - within the regular system.

In the continuation, the situation for kindergarten and school educators and the reform of initial teacher training that is currently underway will be briefly described.

\section{Kindergarten}

In Austria, kindergarten educators are not trained at tertiary or postsecondary level but are qualified through the Training Institutes for Kindergarten Education, which end with the "Matura" (A-level exam). Although the basic teaching principles of these institutes state that, regarding internal differentiation, the children's individual abilities and interests must be taken into account (Curriculum of the Training Institute for Kindergarten Education, 2004), this principle has barely been considered in the respective curricula, where there is little mention of highly able children.

There has, however, recently been a paradigm shift in kindergartens, partly stemming from the aforementioned "Supra-Regional Educational Framework for Elementary Educational Institutions in Austria". This guideline focuses strongly on a strength-based approach, which has led to a reconsideration of talent support in kindergartens. Previously, promoting gifts and talents at the elementary level was strongly discouraged, as children "should be allowed to play and be children". Today, however, educators are increasingly realising that gifted and talented children need to be challenged at an early age (also, of course, through playing) in order for them to stay motivated. This certainly does not mean that four-year-old children should learn Chinese in special courses (in the sense of promoting excellence), but rather that each child is seen 
holistically, in terms of his/her individual potential, and supported accordingly. In the "White Paper Promoting Talent and Excellence", the ÖZBF strongly propagated the promotion of gifts and talents in kindergartens, and has therefore also started a few initiatives in this field of action. All of these initiatives attract wide interest among kindergarten educators, which shows that talent support is finally entering kindergartens:

- In 2012, the ÖZBF started a year-long course on the promotion of gifts and talents in kindergarten (6 EC points), which was attended by over 40 educators. A second course began in February 2014.

- $\quad$ As a result of this course, the ÖZBF is currently working on a manual on how to prepare similar courses, which will then be made available to other institutions. Furthermore, a guideline for talent support in kindergarten has been published by two provincial kindergarten quality managers who participated in the course.

- The ÖZBF is also trying to raise awareness of the promotion of gifts and talents by providing further information, such as articles, posters or colloquia.

The Charlotte Bühler Institute for Practice-Oriented Early Childhood Research (Charlotte Bühler Institut für praxisorientierte Kleinkindforschung) also endeavours to alert kindergarten educators to the importance of talent support at an early age. In 2012, the institution published the so-called "Quality Programme on Talent Support at Elementary Educational Institutions", in which it reviewed the current literature and made recommendations for implementation (Charlotte Bühler Institut, 2011).

As positive as these developments may be, a considerable problem still remains unsolved: kindergarten is not part of the school system, and therefore is unfortunately not considered to be an educational institution by many. This leads, on the one hand, to problems in the transition process from kindergarten to primary school and, on the other hand, to misleading conceptions about the necessary qualification of kindergarten educators. If, as those with a mistaken conception believe, kindergarten were simply an institution where children are looked after but not educated, then the qualification of kindergarten teachers at the secondary level would be justified, as would their lower salaries.

However, according to the OECD study "Starting Strong: Early Childhood Education and Care Policy" (OECD Directorate for Education, 2006), it is no longer justifiable to limit the training of elementary education experts to the secondary level. Studies have shown that higher qualification of experts leads to their providing higher-quality educational services to children (Sylva, 
Melhuish, Sammons, Straj-Blatchford, \& Taggart, 2004). Unfortunately, the opportunity to reform the training of kindergarten teachers within the scope of the current teacher training reform was not seized.

\section{School}

With regard to the qualification of school teachers, teacher training colleges and universities are currently not obliged to include the promotion of giftedness, talent and excellence in their curricula. Although a curriculum on gifted education has been proposed for the training of teachers working in compulsory education, giftedness and talent research and education is by no means an integral part of the curricula at teacher training colleges, let alone a part of university programmes, where prospective medium- and higher-track teachers at general and vocational secondary schools are trained.

In teachers' continued and advanced training, a great number of approaches to making the promotion of talent and excellence a matter of concern for teachers have been proposed; for instance, special courses on gifted and talented education at teacher training colleges, or diploma courses leading to a "Specialist in Gifted Education" degree awarded by the European Council for High Ability (ECHA). Some institutes even offer master's degree courses; for instance, the Danube University Krems or the Teacher Training Colleges of Upper Austria and Vienna (Weilguny, Resch, Samhaber, \& Hartel, 2013).

\section{Current teacher training reform}

With the reform of initial teacher training, new opportunities arise for future teachers to put an increased emphasis on the promotion of gifts and talents within the classroom. The new teacher training in Austria places a strong emphasis on inclusive education, of which the promotion of gifts and talents is more or less considered an integral part. However, it remains to be seen which universities and teacher training colleges will focus on this topic in their new curricula in coming years. Recent developments have shown that this might not be the case in all institutions.

Notwithstanding, the ÖZBF still strongly advocates the integration of talent support into the curricula, and has therefore described contents and competencies on talent support and the promotion of excellence in accordance with the Bologna Declaration. These materials should form a sound basis for universities and teacher training colleges to design curricula and detailed modules for teacher training. 


\section{Research}

On behalf of the Federal Ministry of Science and Research, a survey of giftedness and talent research activities in Austria was undertaken in 2009. The aim of the project was to provide a detailed record and documentation of Austrian research activities in intellectual giftedness and talent in children and youth, focusing on the period between 1990 and 2009 (Preckel, Gräf, Lanig, \& Valerius, 2009).

In summary, the results show that current research activities in giftedness and talent in Austria are sufficient neither in quantity nor quality. Although educational science and teaching methodology are engaged in a host of individual projects and research activities, educational and methodological research is dominated by a few individuals and is barely institutionalised. Universities and teacher training colleges often do not focus explicitly on giftedness and talent research.

Up to now, hardly any research on the concepts of gifted education has been proposed that focuses on the overall school system. Moreover, further action is required regarding "the development and evaluation of programmes for intellectually gifted preschoolers and elementary school children as well as for gifted children from culturally or economically disadvantaged backgrounds" (Preckel, Gräf, Lanig, \& Valerius, 2009, p. 28).

Compared to the number of existing fostering programmes, too little evaluation research is being conducted. "If evaluation studies are conducted, they are mostly done by educational researchers.

Here, stronger cooperation between educational science and psychology would be warranted. The same is true for teacher training" (Preckel, Gräf, Lanig, \& Valerius, 2009).

With regard to research, new initiatives are certainly expected from a new chair of giftedness research and support at the University of Graz, which will be installed in autumn 2014. This new chair is supposed to function as a bridge between psychology and education research, and will also participate in initial teacher training.

\section{Strengths, weaknesses, opportunities and threats in- volved in the proposed strategy}

When evaluating the strengths, weaknesses, opportunities and threats involved in the Austrian policies and strategies for the support of the gifted and talented, the following positive and negative factors can be established. 


\section{Strengths}

- A systemic approach: Austria now strongly follows a systemic approach. "Systemic" means that taking isolated steps in the respective fields of action, e.g., elementary educational institutions, schools or universities, will not suffice. Instead, all of the institutions concerned must join in a coordinated effort so that, in agreement on common objectives and a common vision, they can fulfil their duty of developing talent and excellence.

- A holistic concept of giftedness: In Austria, a multidimensional and dynamic conception of giftedness is prevalent, encompassing the individual's overall potential, which unfolds through lifelong learning and development. This means that educators and parents can focus on a variety of factors when fostering gifted and talented children and youth.

The holistic concept of giftedness has led to a stronger focus on talent support rather than diagnostics. There is a growing awareness that a high IQ score does not necessarily lead to high achievement, and that non-cognitive personality traits such as motivation or a positive selfconcept, as well as a talent-friendly and challenging learning environment, have an even greater influence on talent development than a high IQ.

- $\quad$ From separative measures for a few, to a holistic and inclusive approach for all: In Austria, gifted education has long been considered a supplementary measure to regular schooling. Provided as extracurricular supplements, it was accessible to only a few pupils. However, the promotion of giftedness and talent limited to separative interventions is not enough. In the regular classroom, gifted and talented pupils cannot fully develop their abilities unless teaching and learning offers match their high abilities, as well as their specific needs and interests. When giftedness and talent are promoted only through separation, a great deal of potential of talented and motivated pupils who, for various reasons, do not have access to extracurricular programmes, is lost. Giftedness and talent promotion should therefore be made available in every field of action (Weilguny, Resch, Samhaber, \& Hartel, 2013).

The shift from a separative to an inclusive approach is also reflected in terminology. In Austria, the term "highly gifted" has been unpopular for quite some time, in an effort to avoid labelling. Usually, the more generic terms "gifted" or "talented" are used (Weyringer, 2013). 


\section{Weaknesses}

- Legislation: Although legislation devoted to the promotion of giftedness and talent is enacted in Austria, talent support is not mandatory. The General Decree on the Promotion of Giftedness and Talent issued by the Federal Ministry and the White Paper published by the ÖZBF can only be seen as recommendations.

- $\quad$ Tertiary level: At present, there are hardly any initiatives on the promotion of gifted and excellent students at university level. In the tertiary sector, three key aspects of talent and excellence promotion require further attention: (1) more targeted actions are needed to identify particular abilities, (2) more specific programmes should be initiated to promote excellence, and (3) academic instruction should take greater account of the needs of talented and highly motivated university students.

- Counselling: There is a serious lack of school psychologists to diagnose and counsel gifted pupils. At present, one school psychologist is responsible for up to 10,000 pupils in Austria, handling tasks ranging from career counselling, motivational problems and dyslexia, to eating disorders, $\mathrm{AD}(\mathrm{H}) \mathrm{D}$, violent behaviour and so on. In the kindergarten and the university sectors, there are currently no counselling and support structures at all.

- Research: At present, current research activities in giftedness and talent in Austria are sufficient neither in quantity nor quality.

\section{Opportunities}

- Zeitgeist: Given the current zeitgeist, the promotion of giftedness and excellence is an important subject of discussion. The significance of gifted education is emphasised in many fields and by many institutions and individuals, e.g., the Federal Ministry, the Federation of Austrian Industries, the Austrian Economic Chambers, researchers, bestselling authors, etc. This general trend also accounts for the fact that the terms "giftedness" and "talent" are used more regularly nowadays.

- A combination of top-down and bottom-up processes: One opportunity of Austrian policies and strategies for the support of the gifted and talented is definitely the immanent combination of top-down and bottom-up processes. On the one hand, legislative amendments, funding, motivation and incentives for personnel are provided on the ministerial level. This also includes the establishment and funding of the ÖZBF, which 
acts as a national centre for quality assurance and new initiatives. On the other hand, numerous initiatives on the provincial and local level contribute to the overall picture, such as support programmes at schools and kindergartens, parents' councils, teacher training seminars, psychologists who increasingly offer diagnostics and counselling for the gifted and, last but not least, individual educators who try to provide for gifted children every day.

- The new government programme: In December 2013, the newly elected Austrian Federal Government issued its work programme 2013-2018. The importance of talent support is mentioned in several objectives, highlighting the aforementioned zeitgeist. One of the objectives is to "discover and support all gifted pupils and talents" (Austrian Federal Chancellery, 2013, p. 44). Planned measures include the improvement of talent identification and talent promotion, the strengthening of applied research as well as existing networks and cooperation, and the ongoing development of initial and further teacher training. Other objectives in the programme are the strengthening of high-quality childcare and elementary education to support the talents of all children from the earliest possible age, educational and professional career guidance with a focus on personal strengths, talents and interests, and the promotion of excellence and talent in outstanding young researchers.

- $\quad$ Two ministries are responsible for talent and excellence support: In Austria, not only the Ministry of Education and Women's Affairs but also the Ministry of Science, Research and Economy deal with the topic of talent and excellence support, thus creating a multi-perspective and broad approach. In order to widen this approach even more, it would be desirable to convince other ministries to include talent support in their agenda, most notably the Ministry of Family and Youth, the Ministry of Innovation, and the Ministry of Integration.

- Various school initiatives: Comprehensive school development is a prerequisite for inclusive and integrated talent and excellence promotion in Austria, as it ensures the provision of all pupils with adequate training and fostering. "SQA - Schulqualität Allgemeinbildung" (School Quality in General Education) is an initiative of the Ministry of Education and Women's Affairs to develop and assure quality in current school development programmes. Every school sets up two development plans on two special topics, one of which can be talent support. For those schools interested, the ÖZBF has designed an exemplary SQA development plan for specific support of giftedness and development of excellence. 
"QIBB - Qualitätsinitiative Berufsbildung" (Quality Initiative in Vocational Education) is another policy of the Ministry of Education and Women's Affairs with the aim of introducing a comprehensive quality management system in Austrian vocational schools. Some topics, e.g. transparent assessment and individualisation in teaching, have been emphasised nationwide.

Another school initiative worth mentioning is the introduction of a modular course system (instead of a fixed curriculum) in all upper secondary schools, which also allows acceleration measures for gifted pupils.

School development initiatives like these enable the integration of the promotion of giftedness and the development of excellence so that gifted education is no longer regarded as supplementary but is instead understood as an integral part of school, thus constituting a systematic approach.

- Teacher training reform: The reform of teacher training in Austria could definitely lead to an implementation of gifted education in the new curricula, thus making prospective teachers aware of the fact that the promotion of giftedness and excellence is a core element of teaching (see section Current teacher training reform).

- New chair of giftedness research and support: The appointment of a chair in giftedness research and support at the University of Graz in autumn 2014 will bring about new research initiatives related to giftedness and excellence.

\section{Threats}

- Ideology: Education generally revolves around inclusion, i.e., the inclusion of children with different abilities, ranging from low learning abilities to above-average abilities. However, current ideology in Austria purports that supporting less gifted or "weaker" pupils is more important.

- Zeitgeist: Due to the aforementioned zeitgeist, which propagates the promotion of giftedness and excellence, a myriad of various initiatives have been sprouting in the past few years. Although this is, of course, is a positive development, these initiatives do not always follow the holistic and systemic approach of the "White Paper Promoting Talent and Excellence".

- $\quad$ Federalist system: Austria is a federation consisting of nine quasi-autonomous federal provinces. Executive power is exercised by the federal government as well as by provincial governments. In education, the power of the provinces is relatively strong, giving them the discretion 
to determine the number of personnel they want to allocate to talent support. A national strategy in this regard, as proposed by the White Paper, is thus rather difficult to enforce.

Austria's federalist system also creates a difficult situation in kindergartens: while every province has its own kindergarten laws, kindergarten teachers are employed and paid by municipalities, who have no interest in kindergarten educators being qualified at universities, as they would then demand higher salaries. Kindergarten is not seen as an educational institution, and is therefore not explicitly part of the federal agenda. In short, the system is too federalist and the individual institutions kindergartens, primary schools, secondary schools, grammar schools and universities - do not work together, thus creating problems at the transitions.

- Standardisation: At the moment, the education sector is concentrating on standardisation. A standardised, skills-based school-leaving certificate has been established, and standards at grades 4 and 8 are examined to ensure that every school teaches the necessary and basic skills in certain subjects to a high level of quality. Although the idea behind standardisation per se is praiseworthy, there is an inherent problem: teaching to the test is starting to creep into tuition, while individualisation is neglected.

- $\quad$ Finance and money: Like most European countries, Austria is currently struggling with a growing budget deficit, making severe budget cuts in all spheres of life (schools, kindergartens, etc.) a necessity.

- Excessive demands on educational institutions: Schools and kindergartens are overburdened, as there is a severe lack of support structures (e.g., social workers, psychologists). Teachers are forced to take on more and more functions and do not feel they have enough time and strength to concentrate on the support of gifted and talented pupils.

\section{Conclusion - an optimistic outlook}

Austria has introduced and implemented a variety of effective strategies and measures for talent promotion and gifted education over the past decades. Several laws have been passed to facilitate the promotion of giftedness and excellence. Initiatives and activities such as summer academies, talent courses and further training courses are offered in every province. School quality initiatives such as SQA and QIBB provide an opportunity for the continuous promotion of gifts and talents. 
The ministries have taken a significant step forward with the establishment of an interministerial Giftedness Research and Gifted Education Task Force for the provision of the gifted and talented, the implementation of coordinating centres in every Austrian province and the foundation of the Austrian Research and Support Centre for the Gifted and Talented (ÖZBF) as a national institution. The current governmental programme explicitly mentions gifted education as an important objective. Finally, an aspect of paramount importance: many Austrian educators have committed themselves to the promotion of gifted and talented children and youth in their daily work, and they contribute greatly to the development of potentials.

On the whole, public awareness - and acceptance - of related governmental initiatives is growing, and the promotion of giftedness and excellence is increasingly regarded as a natural element in teaching, as every child has potentials that simply need fostering.

It will predominantly be the responsibility of the Task Force and the ÖZBF to sustain and optimise these positive developments and to ensure their continual monitoring and evaluation, while it will be the responsibility of every promoter of giftedness and excellence to continue their endeavours, and of every potential promoter to initiate new endeavours.

\section{Acknowledgments}

I would like to thank my colleague Dr Sandra Thomä, who assisted with preparing some sections of the present paper, as well as proofreading and providing me with useful comments and suggestions.

\section{References}

Austrian Federal Chancellery (2013). Work programme of the Austrian Federal Government 2013-2018. Austria. A story of success. Retrieved 29 March 2014 from www.bka.gv.at/DocView. $\operatorname{axd}$ ?CobId $=53588$.

Charlotte Bühler Institut, on behalf of the Austrian Provincial Government Offices, the Vienna Magistrate \& the Federal Ministry of Education, Arts, and Culture. (2009).

Bundesländerübergreifender BildungsRahmenPlan für elementare Bildungseinrichtungen in Österreich. Wien: BMUKK.

Charlotte Bühler Institut. (2011). Qualitätsprogramm für (Hoch-)Begabtenförderung und (Hoch-)

Begabungsforschung am Beispiel elementarer Bildungseinrichtungen. Wien: Charlotte Bühler Institut. Curriculum of the Training Institute for Kindergarten Education (2004). Retrieved 11 January 2014 from www.abc.berufsbildendeschulen.at/upload/655_lp_bakip_anl.pdf 
Federal Ministry of Education, Science, and Culture. (2005). Erlass Besser Fördern: Schülerinnen und Schüler individuell fördern und fordern. Rundschreiben No. 11/2005 (28 June 2005).

Federal Ministry of Education, Science, and Culture. (2007). Erlass "Initiative "25+":

Individualisierung des Unterrichts“. Rundschreiben No. 9/2007 (19 June 2007).

International Panel of Experts for Gifted Education. (2009). Professional Promotion of the Gifted and

Talented. Recommendations for the Qualification of Experts in Gifted Education. Salzburg: ÖZBF.

OECD Directorate for Education. (2006). Starting Strong: Early Childhood Education and

Care Policy. Länderbericht für Österreich. Retrieved 23 February 2014 from www.oecd.org/

dataoecd/57/58/36657509.pdf

Oswald, F., \& Weilguny, W. M. (2005). Schulentwicklung durch Begabungs- und Begabtenförderung.

Impulse zu einer begabungsfreundlichen Lernkultur. Salzburg: ÖZBF.

Preckel, F., Gräf, J., Lanig, M., \& Valerius, S. (2009). Begabungsforschung in Österreich. Erstellung einer Forschungslandschaft und Skizzierung der Forschung in der Schweiz und Deutschland. Projekt im Auftrag des ÖZBF und mit Finanzierung durch das BMWF. Salzburg: ÖZBF.

Rosner, W. (2004). Ein Pionier der Begabtenförderung. In N. Blaichinger (Ed.), Gerhard Schäffer. 25 Jahre Bildungspolitik für Österreich (pp. 119-136). Aspach: edition innsalz.

Schwabe, M., \& Gumpoldsberger, H. (2008). Regionale Disparitäten der Verteilung der Schüler und Schülerinnen auf Schultypen in der Sekundarstufe. Statistische Nachrichten 12/2008. Retrieved 22 March 2014 from www.statistik.at/web_de/static/regionale_disparitaeten_der_verteilung_der_ schueler_und_schuelerinnen_auf_035591.pdf

Sylva, K., Melhuish, E., Sammons, P., Siraj-Blatchford, I., \& Taggart, B. (2004). The Effective Provision of Pre-School Education (EPPE) Project. Final Report. A Longitudinal Study Funded by the DfES 1997-2004. Retrieved 22 February 2004 from http://eppe.ioe.ac.uk/

Weilguny, W. M., Resch, C., Samhaber, E., \& Hartel, B. (2013). White Paper Promoting Talent and Excellence. Salzburg: ÖZBF.

Weilguny, W. M., \& Rosner, W. (2012). Das Beratungskonzept des Österreichischen Zentrums für Begabtenförderung und Begabungsforschung (ÖZBF) - Aufriss einer Entwicklung. In A. Ziegler,

R. Grassinger, \& B. Harder (Eds.), Konzepte der Hochbegabtenberatung in der Praxis (pp. 209-225).

Münster: LIT-Verlag.

Weyringer, S. (2013). Gifted Education in Austria. Journal for the Education of the Gifted, 36(3), $365-383$.

Ziegler, A., \& Stoeger, H. (2007). The Germanic View of Giftedness. In S. N. Philipson \& M. McCann (Eds.), Conceptions of Giftedness: Sociocultural Perspectives (pp. 65-98). Mahwah: Lawrence Erlbaum. 


\section{Biographical note}

Claudia Resch, MMag. Dr., is executive manager of the Austrian Research and Support Centre for the Gifted and Talented (ÖZBF). She is also executive manager of the International Panel of Experts for Gifted Education and a member of the Giftedness Research and Gifted Education Task Force, an interministerial steering committee. She studied History and English (teacher accreditation program) at the University of Salzburg. In 2007 she obtained her Ph.D. in History. 